\title{
Project Team Perception of Causes of Building Cost Overruns: A Reflection in Tanzania
}

\author{
Harriet Eliufoo \\ School of Architecture, Construction Economics and Management, Building Economics Department, Ardhi University, Dar es \\ Salaam P.O.Box 35176, Tanzania
}

\begin{abstract}
The paper provides an empirical insight into the significance of shared cognition reflected in the perception of key actors in selected construction projects. It has explored how clients, consultants and contractors prioritize causes of cost overrun in building projects in Tanzania and measured the statistical variance in their order of rank. A total of 55 respondents were selected from public projects that had experienced cost overruns. The results show an inclination of the top 4 causes of cost overrun being technical and originate from internal sources. The Spearman correlation coefficient established a strong positive correlation in the ranking of causes of cost overrun in construction project by clients, consultants and contractors, suggesting a shared cognition is in place for the project team. The outcome provides a good base for contemplating success of mitigation measures for cost overruns and reiterates the significance for a shared cognition for project team success.
\end{abstract}

Key words: Cost overrun, construction project, shared cognition, team success.

\section{Introduction}

Although the significance of teams in problem solving has been discerned as core in the success of finding solutions, this however does not only rely on an individual team member but rather on team members' complementary expertise, and more importantly, their collective problem solving ability. Understanding collective components and processes during team-based problem solving has been underscored as essential [1].

Chatterjee [2] advocating the significance of collective shared mental models in team work acknowledged the fact that although teams' compositions are inherently varied and heterogeneous, nonetheless are expected to recognize, share and assimilate diverse information so as to be productive. They [2] further state when effective, have a potential of creating shared mental models of tasks, identify organizational expertise and reduce information

Corresponding author: Harriet Eliufoo, senior lecturer, research fields: total quality management, gender and contract administration. E-mail: heliufoo@yahoo.com. management burdens within the team.

Che Ibrahim et al. [3] on the other hand emphasized formation of integral teams for successful project delivery; reiterating on the fact that performance of the construction industry is subjective to how the knowledge and experience of individuals is integrated together as a team; and that such a condition may be hindered by lack of collaboration, inconsistent shared vision, poor communication and inadequate participation of team members. Likewise Jetu and Riedl [4] have stressed the importance of shared vision and a unified sense of purpose by team members for successful integration of individual thoughts and actions to achieve project objectives.

\subsection{Collective Cognitive and Team Work}

Examining similarity between knowledge and belief structures among team members should add a missing dimension to the construct of shared cognition and may help to reveal a stronger association with team effectiveness [5] that the concept of shared cognition, may help explain the performance of effective teams. Standifer et al. [6] 
acknowledged the link of shared cognitions to teams' ability to adapt, coordinate, and reach consensus; and the fact that past research has showed teams with shared cognitions enjoy benefits like enhanced coordination of task activities and enhanced team performance.

Standifer et al. [6] have recognized prior researches that purport coordinative efforts as most effective when temporal perspectives and behaviors of team members are aligned. The authors underscore the significance of teams exhibiting STC (shared temporal cognition) in improving ability to pace activities and determine important temporal milestones.

This paper has taken team shared cognition and shared vision as congruent to team members' perspective. The study has henceforth collected perspectives of key project actors on a typical construction challenge, cost overrun.

In support of Dada's [7] findings that cost growth or cost overrun in construction projects is significantly correlated with client-contractor relationship, consultant-contractor relationship, client-consultantcontractor relationship and in-house team relationships, this paper subsequently makes a presumption that for effective mitigation of cost overruns in building projects, it is imperative for the team of key actors, clients, consultants and contractors to be thinking in tandem.

A further notion posited is that the project actors should not only work as a team or in unison, but should also think in unison; that a cognitive commonality exists. It is the author's view that to mitigate cost overruns a common perception of factors attributing to cost overruns is essential.

It is from this background that this study has taken to assess the perception of key actors of factors causing cost overruns in building projects.

The study hence aims to: assess how clients, consultants and contractors prioritize causes of cost overrun in building projects; and also measure the dichotomy and statistical significance in ranking order of causes of cost overruns in building projects of clients, consultants and contractors.

Whilst the extant literature provides insight into factors leading to cost overruns and their effects on construction projects in various countries [8-13], the studies however have not considered key actors' perception with regard to causes of cost overruns. The studies have not recognized the significance of collective cognitive thinking and the project team performance.

In filling the gap, the study has analyzed key actors' perspective in the identification of factors attributing to cost overruns, a factor that is significant in influencing decisions for effective cost control of building projects. In essence, the study underscores the significance of collective cognitive thinking by team players as an essential tool for success in mitigation of cost overruns.

The outcome of the study is expected to be ground for enabling learning for countries with similar economies.

\section{Literature Review}

\subsection{Cost Overrun Definition}

Cost overrun occurs when the final cost or expenditure of a project exceeds the original estimation cost [14]. Amoa-Abban and Allotey [15] defined cost overrun as the amount by which actual costs exceeds the baseline or an approved cost. In his definition, Avots [14] considered cost overrun as the difference between the original cost and the actual cost when the project is completed. In this study, cost overrun is defined as the difference between the agreed cost (contract amount) and the final actual cost of a construction project at completion, agreed by the client/employer and the contractor.

\subsection{Causes of Cost Overrun}

Cost overrun is a major problem in both developed and developing countries [7, 9, 15]. Causes of cost overrun in construction projects are varied, where 
some of them are hard to predict and also difficult to manage [16]. According to Arditi et al. [17], in a study made in Turkey, the prominent sources for cost overrun were found to be inflationary pressures, construction delays, inaccurate cost estimates and unexpected sub soil conditions. Kaming et al. [18] similarly identified the same for high rise buildings in Indonesia but identified the degree of project complexity as an additional factor. Mansfield, Ugwu and Doran [19], on the other hand, attributed cost overrun to problems in financing and payment arrangements, poor contract management, material shortages, changes in site conditions, design changes, mistakes and discrepancies in contract documents, price fluctuations, inaccurate estimates, delays, additional work, shortening of contract periods, and fraudulent practices and kickbacks. Amoa-Abban and Allotey [15] citing Cox (2007), on the other hand, gave a view of project owners of causes of cost overrun as: incomplete drawings, poor pre-planning process, escalating cost of materials, lack of timely decisions and excessive changes. Qualitative factors affecting project cost such as client's priority on construction time, contractors' organizational ability, procurement methods and market conditions, have been also identified [20]; so is improperly managed risk and uncertainty [8].

A dominant factor of cost overrun identified is inaccurate estimation of original cost of a project at preliminary estimation [21] or at tender stage [22]. This, however, is debated in Refs. [8, 23, 24] that had mentioned political and economic motives in intentional underestimation typical of large public projects. Flyvberg [23, 25], on the other hand, had cautioned on the "Machiavelli factor" as typical for mega projects.

\section{Methodology}

A survey was made through questionnaires and interviews to consultants, clients and contractors that were purposely selected. The selection criteria of respondents were based on the fact that they had worked on a public owned building project that had cost overrun beyond $30 \%$ of the original contract sum. A total of 55 respondents provided the required information. Questionnaires were distributed to 15 engineers, 25 contractors and 15 consultants. The questionnaires had sought the perception from clients, consultants and contractors who were involved in the selected building construction projects.

Analysis was done using both descriptive and inferential statistics. The Likert's scale of five ordinal measures of agreement to each statement 1, 2, 3, 4, and 5 was used to calculate the mean score for each variable indicated in the questionnaire and used to determine the relative ranking. A total of 44 variables as sources of cost overruns were included in the questionnaire for the respondents to respond upon.

\section{Findings and Discussion}

The MS (mean score) of the three groups of respondents, clients, consultant and contractors on the causes of cost overrun was established. The study took variables of cost overrun with mean scores less than 2 to reflect a disagree position of respondent and a mean score greater than 2 as an affirmation of a variable attributing to cost overrun, $(1.99 \leq s \leq 2)$, where $s$ represents cost overrun. The results are indicated in Table 1.

Respondents ranking of the top five causes of cost overrun (see Table 1) are: inflation or increase of construction materials, that had a weighted mean score of 5.75; errors and omission in design, a weighted mean score of 4.59; change of plan or scope of the work, a weighted mean score of 4.46; change in design, drawing a weighted mean score of 4.44; and change in specifications or unclear specification, a weighted mean score of 4.31. Except for the first factor of cost increases, one observes the other factors are of technical nature and emerge from internal causes.

Another observation made from Table 1 is the fact that each group of respondents' rank of the cause of 
Table 1 Mean scores clients, consultants and contractors.

\begin{tabular}{|c|c|c|c|c|c|}
\hline \multirow{2}{*}{ Causes of cost overrun } & MS & MS & MS & Average & Rank \\
\hline & (a) & (b) & (c) & (d) & (e) \\
\hline Inflation or increase in the cost of materials & 5.75 & 5.67 & 5.83 & 5.75 & 1 \\
\hline Errors: omission in design & 4.54 & 4.80 & 4.44 & 4.59 & 2 \\
\hline Change of plan or scope of the work & 4.21 & 4.60 & 4.56 & 4.46 & 3 \\
\hline Change in design and drawing & 4.63 & 4.80 & 3.89 & 4.44 & 4 \\
\hline Change/unclear specification & 4.75 & 4.40 & 3.78 & 4.31 & 5 \\
\hline Inaccurate quantity/excess quantity during construction & 5.29 & 3.60 & 3.50 & 4.13 & 6 \\
\hline Cost underestimation & 4.54 & 3.60 & 3.89 & 4.01 & 7 \\
\hline Scope for the contractor not well defined & 3.88 & 4.60 & 3.39 & 3.96 & 8 \\
\hline Kickbacks/fraudulent practices & 4.75 & 3.60 & 3.39 & 3.91 & 9 \\
\hline Delay of drawings and/order requests by contractor & 4.04 & 3.80 & 3.89 & 3.91 & 10 \\
\hline Supplementary/additional agreement & 4.63 & 3.80 & 2.89 & 3.77 & 11 \\
\hline Delays in prompt decision & 3.13 & 4.20 & 3.83 & 3.72 & 12 \\
\hline Noncompliance of design with client's requirements & 3.63 & 3.80 & 3.72 & 3.72 & 13 \\
\hline Insufficient geotechnical investigation & 3.88 & 3.60 & 3.56 & 3.68 & 14 \\
\hline Differing site conditions & 2.23 & 4.60 & 3.94 & 3.59 & 15 \\
\hline Errors in setting out basing on incorrect written data supplied by the engineer & 4.00 & 3.20 & 3.50 & 3.57 & 16 \\
\hline Substitution of materials & 2.37 & 4.00 & 4.22 & 3.53 & 17 \\
\hline Difficulties in obtaining construction materials in the local market & 4.83 & 2.00 & 3.56 & 3.46 & 18 \\
\hline Unforeseen problems & 2.34 & 4.00 & 3.94 & 3.43 & 19 \\
\hline Conflict between contract documents & 4.04 & 3.00 & 3.11 & 3.38 & 20 \\
\hline Ambiguities or discrepancies of documents & 2.13 & 3.20 & 4.56 & 3.30 & 21 \\
\hline Addition or enhancement required by client or end users & 2.88 & 4.20 & 2.44 & 3.17 & 22 \\
\hline Lack of planning and coordination or less emphasis to planning & 3.20 & 3.00 & 3.32 & 3.17 & 23 \\
\hline Poor communication; contractor, consultant, and client & 2.75 & 3.60 & 3.06 & 3.14 & 24 \\
\hline Cost associated with test of samples not provided in the contract & 1.67 & 4.80 & 2.89 & 3.12 & 25 \\
\hline Lack of end users involvement & 2.63 & 2.80 & 3.89 & 3.11 & 26 \\
\hline Increase in tax/change in government fiscal/monetary policies & 3.33 & 2.00 & 3.94 & 3.09 & 27 \\
\hline Executive bureaucracy in client's organization & 3.58 & 2.80 & 2.78 & 3.05 & 28 \\
\hline Financial problems or funding problems & 3.92 & 2.00 & 3.00 & 2.97 & 29 \\
\hline Noncompliance of design with government regulations & 3.00 & 1.20 & 4.72 & 2.97 & 30 \\
\hline $\begin{array}{l}\text { Failure to identify risks and institute necessary and timely remedy and control } \\
\text { program }\end{array}$ & 3.35 & 3.20 & 2.17 & 2.91 & 31 \\
\hline Poor procurement & 3.17 & 2.20 & 3.28 & 2.88 & 32 \\
\hline Inadequate project objectives & 2.71 & 2.00 & 3.89 & 2.87 & 33 \\
\hline Inappropriate/inexperience contractor & 3.63 & 2.00 & 2.94 & 2.86 & 34 \\
\hline Change of schedule & 2.92 & 3.00 & 2.56 & 2.83 & 35 \\
\hline $\begin{array}{l}\text { Failure on the part of the employer to give possession of the site to contractor as } \\
\text { agreed in the contract }\end{array}$ & 2.46 & 2.80 & 3.17 & 2.81 & 36 \\
\hline Obstinate nature of the owner & 2.21 & 2.20 & 3.83 & 2.75 & 37 \\
\hline Acceleration required by the client & 3.94 & 2.00 & 2.17 & 2.70 & 38 \\
\hline Safety considerations & 2.34 & 3.40 & 2.33 & 2.69 & 39 \\
\hline Indemnities that the employer has contractually undertaken to assume & 2.25 & 3.2 & 2.56 & 2.67 & 40 \\
\hline Contractors bankruptcy & 2.72 & 2.82 & 2.34 & 2.63 & 41 \\
\hline Political pressures at the time of construction & 2.65 & 1.8 & 3.11 & 2.52 & 42 \\
\hline Technology change & 2.53 & 2.80 & 2.11 & 2.48 & 43 \\
\hline Fossils or things of geological interest & 2.25 & 2.00 & 2.06 & 2.10 & 44 \\
\hline
\end{tabular}

Note: (a) = MS client; (b) = MS consultant; (c) = MS contractor; $(d)=$ average; $(e)=$ rank. 
cost overrun varies. It is hence of interest to know how significant this variance is.

The Spearman $(I s)$ rank correlation coefficient was used for measuring the differences in ranking between two groups of respondents scoring for the various factors, i.e., clients versus consultants, clients versus contractors and consultants versus contractors.

The Spearman $(I s)$ rank correlation coefficient for any pairs of ranking is given by the following formula:

$$
I_{s}=1-\frac{6 \times\left(\sum d i^{2}\right)}{N \cdot\left(N^{2}-1\right)}
$$

where:

$I_{S}=$ Spearman rank correlation coefficient;

$d i=$ the difference in ranking between each pair of factors;

$N=$ number of factors (variables).

Furthermore, a hypothesized test for agreement on factors causing cost overrun between stakeholders involved in the building construction industry was done. The test was done to assess whether a consensus of opinions existed among the respondents.

The null hypothesis (Ho): There is no agreement in the ranking of causes of cost overrun between two groups of respondents.

The alternative Hypothesis (Ha): There is agreement in the ranking of causes of cost overrun between two groups of respondents.

A comparison of ranking was initially made between the client and consultant respondents. The results are as shown in Table 2 .

The computed Spearman correlation coefficient $I S$ is:

$$
I s=1-\frac{6 \times 9,879}{44^{3}-44}
$$

For better analysis, the study made a categorization of the ranking, whereas a rank level of "1-14" reflects a "high" influencing factor, a rank level of "15- 28" for a "moderate" influencing factor and a level ranging from "29-44" as a " least" influencing factor.

From Table 2, it is noted that typically differences exist in the ranking of clients and consultant. Enormous differences noted for a variable such as "ambiguities or discrepancies of documents" ranked by clients as the last but one factor (the 43rd out of the 44 factors); whereas consultants rank it as a "4th" factor, as a "high" influencing factor. Despite such large disparities, the results also show factors that have the same value of rank. These are "inflation or increase in the cost of materials ranked by both as the number one factor. "Financial or funding problems" perceived by both in the "high" influence group and "change in design and drawings" perceived to be in the "moderate" influence group.

Similarly, a comparison in ranking was made between client respondents and contractor respondents. The results are as shown in Table 3.

The computed Spearman correlation coefficient $I_{S}$ is:

$$
I_{s}=1-\frac{6 \times 11,114}{44^{3}-44}=0.2168
$$

From Table 3, one notes factors given the same rank by client and contractor respondents are only "inflation or increase in the cost of materials" being ranked number one factor and "changes in plan or scope of work" being in the " moderate" influence factor.

A correlation of ranking between consultant and contractors respondents was done and the Spearman correlation coefficient was computed. The results are shown in Table 4.

The computed Spearman correlation coefficient $I s$ of consultant against contractor respondents is:

$$
I_{s}=1-\frac{6 \times 9,014}{44^{3}-44}=0.3648
$$

As for the other groups (see Tables 2 and 3), consultants and contractors identified "inflation or increase in the cost of materials" as the number one influencing factor of causes of cost overruns. "Kickbacks and fraudulent practices" also perceived the same, but given a "least" influence category by the consultants and contractors. 
Table 2 Correlation in rank-client and consultant.

\begin{tabular}{|c|c|c|c|c|c|c|}
\hline \multirow[t]{2}{*}{ Causes of cost overrun } & MS of client & Rank & $\begin{array}{l}\text { MS of } \\
\text { consultant }\end{array}$ & Rank & $d i$ & $d i^{2}$ \\
\hline & (a) & (b) & (c) & (d) & (e) & (f) \\
\hline Inflation or increase in the cost of materials & 5.75 & 1 & 5.67 & 1 & 0 & 0 \\
\hline Errors and omission in design & 4.54 & 9 & 4.80 & 2 & 7 & 49 \\
\hline Change of plan or scope of the work & 4.21 & 10 & 4.60 & 5 & 5 & 25 \\
\hline Change in design and drawing & 4.63 & 6 & 4.80 & 3 & 3 & 9 \\
\hline Change in specifications or unclear specification & 4.75 & 4 & 4.40 & 7 & -3 & 9 \\
\hline Inaccurate quantity estimate or excess quantity during construction & 5.29 & 2 & 3.60 & 14 & -12 & 144 \\
\hline Cost underestimation & 4.54 & 8 & 3.60 & 15 & -7 & 49 \\
\hline The scope of work for the contractor is not well defined & 3.88 & 16 & 4.60 & 5 & 11 & 121 \\
\hline Kickbacks and fraudulent practices & 4.75 & 5 & 3.60 & 16 & -11 & 121 \\
\hline Delay of drawings and/or order requested by contractor & 4.04 & 11 & 3.80 & 11 & 0 & 0 \\
\hline Supplementary/additional agreement & 4.63 & 7 & 3.80 & 12 & -5 & 25 \\
\hline Delays in prompt decision making process & 3.13 & 25 & 4.20 & 7 & 18 & 324 \\
\hline Noncompliance of design with client's requirements & 3.63 & 18 & 3.80 & 13 & 5 & 25 \\
\hline Insufficient geotechnical investigation & 3.88 & 17 & 3.60 & 17 & 0 & 0 \\
\hline Differing site conditions & 2.23 & 40 & 4.60 & 6 & 34 & 1,156 \\
\hline Errors in setting out basing on incorrect written data supplied by the engineer & 4.00 & 13 & 3.20 & 20 & -7 & 49 \\
\hline Substitution of materials & 2.37 & 35 & 4.00 & 9 & 26 & 676 \\
\hline Difficulties in obtaining construction materials in the local market & 4.83 & 3 & 2.00 & 34 & -31 & 961 \\
\hline Unforeseen problems & 2.34 & 36 & 4.00 & 10 & 26 & 676 \\
\hline Conflict between contract documents & 4.04 & 12 & 3.00 & 24 & -12 & 144 \\
\hline Ambiguities or discrepancies of documents & 2.13 & 42 & 3.20 & 21 & 21 & 441 \\
\hline Addition or enhancement required by client or end users & 2.88 & 28 & 4.20 & 8 & 20 & 400 \\
\hline Lack of planning and coordination or less emphasis to planning & 3.20 & 23 & 3.00 & 25 & -2 & 4 \\
\hline Poor communication among contractor, consultant, and the client & 2.75 & 29 & 3.60 & 18 & 11 & 121 \\
\hline Cost associated with test of samples not provided in the contract & 1.67 & 43 & 4.80 & 4 & 39 & 1,521 \\
\hline Lack of end users involvement & 2.63 & 32 & 2.80 & 28 & 4 & 16 \\
\hline Increase in tax/change in Government fiscal/monetary policies & 3.33 & 22 & 2.00 & 35 & -13 & 169 \\
\hline Executive bureaucracy in the client's organization/staff & 3.58 & 20 & 2.80 & 29 & -9 & 81 \\
\hline Financial problems or funding problems & 3.92 & 15 & 2.00 & 36 & -21 & 441 \\
\hline Noncompliance of design with government regulations & 3.00 & 26 & 1.20 & 42 & -16 & 256 \\
\hline $\begin{array}{l}\text { Failure to identify risks and institute necessary and timely remedy and } \\
\text { control program }\end{array}$ & 3.35 & 21 & 3.20 & 22 & -1 & 1 \\
\hline Poor procurement & 3.17 & 24 & 2.20 & 32 & -8 & 64 \\
\hline Inadequate project objectives & 2.71 & 29 & 2.00 & 37 & -8 & 64 \\
\hline Inappropriate/inexperience contractor & 3.63 & 19 & 2.00 & 38 & -19 & 361 \\
\hline Change of schedule & 2.92 & 27 & 3.00 & 26 & 1 & 1 \\
\hline $\begin{array}{l}\text { Failure on the part of the employer to give possession of the site to } \\
\text { contractor as agreed in the contract }\end{array}$ & 2.46 & 34 & 2.80 & 30 & 4 & 16 \\
\hline Obstinate nature of the owner & 2.21 & 41 & 2.20 & 33 & 8 & 64 \\
\hline Acceleration required by the client & 3.94 & 14 & 2.00 & 39 & -25 & 625 \\
\hline Safety considerations & 2.34 & 37 & 3.40 & 19 & 18 & 324 \\
\hline Indemnities that the employer has contractually undertaken to assume & 2.25 & 38 & 3.20 & 23 & 15 & 225 \\
\hline Contractors bankruptcy & 2.72 & 30 & 2.82 & 26 & 4 & 16 \\
\hline Political pressures at the time of construction & 2.65 & 31 & 1.80 & 41 & -10 & 100 \\
\hline Technology change & 2.53 & 33 & 2.80 & 31 & 2 & 4 \\
\hline Fossils or discovery of things of geological interest & 2.25 & 39 & 2.00 & 40 & $\begin{array}{l}-1 \\
\sum d i^{2}\end{array}$ & $\begin{array}{l}1 \\
9,879\end{array}$ \\
\hline
\end{tabular}

Note: (a) = MS client; (b) = client ranking; (c) = MS consultant; (d) = consultant ranking; (e) = difference in rank; (f) = square of difference in rank. 
Table 3 Correlation in rank-client and contractor.

\begin{tabular}{|c|c|c|c|c|c|c|}
\hline \multirow{2}{*}{ Causes of cost overrun } & \multirow{2}{*}{$\begin{array}{l}\text { MS } \\
\text { (a) }\end{array}$} & \multirow{2}{*}{$\begin{array}{l}\text { Rank } \\
\text { (b) }\end{array}$} & \multirow{2}{*}{$\begin{array}{l}\text { MS } \\
\text { (c) }\end{array}$} & \multirow{2}{*}{$\begin{array}{l}\text { Rank } \\
\text { (d) }\end{array}$} & \multirow{2}{*}{$\begin{array}{l}d i \\
\text { (e ) }\end{array}$} & \multirow{2}{*}{$\begin{array}{l}\mathrm{di}^{2} \\
\text { (f) }\end{array}$} \\
\hline & & & & & & \\
\hline Inflation or increase in the cost of materials & 5.75 & 1 & 5.83 & 1 & 0 & 0 \\
\hline Errors and omission in design & 4.54 & 9 & 4.44 & 5 & 4 & 16 \\
\hline Change of plan or scope of the work & 4.21 & 10 & 4.56 & 3 & 7 & 49 \\
\hline Change in design and drawing & 4.63 & 6 & 3.89 & 13 & -7 & 49 \\
\hline Change in specifications or unclear specification & 4.75 & 4 & 3.78 & 17 & -13 & 169 \\
\hline Inaccurate quantity estimate or excess quantity during construction & 5.29 & 2 & 3.50 & 21 & -19 & 361 \\
\hline Cost underestimation & 4.54 & 8 & 3.89 & 11 & -3 & 9 \\
\hline The scope of work for the contractor is not well defined & 3.88 & 16 & 3.39 & 24 & -8 & 64 \\
\hline Kickbacks and fraudulent practices & 4.75 & 5 & 3.39 & 23 & -18 & 324 \\
\hline Delay of drawings and/or order requested by contractor & 4.04 & 11 & 3.89 & 10 & -1 & 1 \\
\hline Supplementary/additional agreement & 4.63 & 7 & 2.89 & 34 & -27 & 729 \\
\hline Delays in prompt decision making process & 3.13 & 25 & 3.83 & 16 & 9 & 81 \\
\hline Noncompliance of design with client's requirements & 3.63 & 18 & 3.72 & 18 & 0 & 0 \\
\hline Insufficient geotechnical investigation & 3.88 & 17 & 3.56 & 19 & -2 & 4 \\
\hline Differing site conditions & 2.23 & 40 & 3.94 & 8 & 32 & 1,024 \\
\hline Errors in setting out basing on incorrect written data supplied by the engineer & 4.00 & 13 & 3.50 & 22 & -9 & 81 \\
\hline Substitution of materials & 2.37 & 35 & 4.22 & 6 & 29 & 841 \\
\hline Difficulties in obtaining construction materials in the local market & 4.83 & 3 & 3.56 & 20 & -17 & 289 \\
\hline Unforeseen problems & 2.34 & 36 & 3.94 & 9 & 27 & 729 \\
\hline Conflict between contract documents & 4.04 & 12 & 3.11 & 28 & -16 & 256 \\
\hline Ambiguities or discrepancies of documents & 2.13 & 42 & 4.56 & 4 & 38 & 1,444 \\
\hline Addition or enhancement required by client or end users & 2.88 & 28 & 2.44 & 38 & -10 & 100 \\
\hline Lack of planning and coordination or less emphasis to planning & 3.20 & 23 & 3.32 & 25 & -2 & 4 \\
\hline Poor communication among contractor, consultant, and the client & 2.75 & 29 & 3.06 & 30 & -1 & 1 \\
\hline Cost associated with test of samples not provided in the contract & 1.67 & 43 & 2.89 & 33 & -10 & 100 \\
\hline Lack of end users involvement & 2.63 & 32 & 3.89 & 14 & 18 & 324 \\
\hline Increase in tax/change in government fiscal/monetary policies & 3.33 & 22 & 3.94 & 7 & 15 & 225 \\
\hline Executive bureaucracy in the client's organization/staff & 3.58 & 20 & 2.78 & 35 & -15 & 225 \\
\hline Financial problems or funding problems & 3.92 & 15 & 3.00 & 31 & -16 & 256 \\
\hline Noncompliance of design with government regulations & 3.00 & 26 & 4.72 & 2 & 24 & 576 \\
\hline $\begin{array}{l}\text { Failure to identify risks and institute necessary and timely remedy and control } \\
\text { program }\end{array}$ & 3.35 & 21 & 2.17 & 43 & -22 & 484 \\
\hline Poor procurement & 3.17 & 24 & 3.28 & 26 & -2 & 4 \\
\hline Inadequate project objectives & 2.71 & 29 & 3.89 & 12 & 17 & 289 \\
\hline Inappropriate/inexperience contractor & 3.63 & 19 & 2.94 & 32 & -13 & 169 \\
\hline Change of schedule & 2.92 & 27 & 2.56 & 19 & 8 & 64 \\
\hline $\begin{array}{l}\text { Failure on the part of the employer to give possession of the site to contractor as } \\
\text { agreed in the contract }\end{array}$ & 2.46 & 34 & 3.17 & 27 & 7 & 49 \\
\hline Obstinate nature of the owner & 2.21 & 41 & 3.83 & 14 & 27 & 729 \\
\hline Acceleration required by the client & 3.94 & 14 & 2.17 & 42 & -28 & 784 \\
\hline Safety considerations & 2.34 & 37 & 2.33 & 40 & -3 & 9 \\
\hline Indemnities that the employer has contractually undertaken to assume & 2.25 & 38 & 2.56 & 37 & 1 & 1 \\
\hline Contractors bankruptcy & 2.72 & 30 & 2.34 & 39 & -9 & 81 \\
\hline Political pressures at the time of construction & 2.65 & 31 & 3.11 & 29 & 2 & 4 \\
\hline Technology change & 2.53 & 33 & 2.11 & 44 & -11 & 121 \\
\hline Fossils or discovery of things of geological interest. & 2.25 & 39 & 2.06 & 41 & -2 & 4 \\
\hline & & & & & $\sum d i^{2}$ & 11,123 \\
\hline
\end{tabular}

Note: (a) = MS client; (b) = client ranking; (c) = MS contractor; (d) = contractor ranking; (e) = difference in rank; (f) = square of difference in rank. 
Table 4 Correlation of ranking—consultant and contractor.

\begin{tabular}{|c|c|c|c|c|c|c|}
\hline \multirow{2}{*}{ Causes of cost overrun } & \multirow{2}{*}{$\frac{\mathrm{MS}}{\text { (a) }}$} & \multirow{2}{*}{$\begin{array}{l}\text { Rank } \\
\text { (b) }\end{array}$} & \multirow{2}{*}{$\begin{array}{l}\text { MS } \\
\text { (c) }\end{array}$} & \multirow{2}{*}{$\begin{array}{l}\text { Rank } \\
\text { (d) }\end{array}$} & \multirow{2}{*}{$\begin{array}{l}d i \\
(\mathrm{e})\end{array}$} & \multirow{2}{*}{$\begin{array}{l}d i^{2} \\
\text { (f) }\end{array}$} \\
\hline & & & & & & \\
\hline Inflation or increase in the cost of materials & 5.67 & 1 & 5.83 & 1 & 0 & 0 \\
\hline Errors and omission in design & 4.80 & 2 & 4.44 & 5 & -3 & 9 \\
\hline Change of plan or scope of the work & 4.60 & 5 & 4.56 & 3 & 2 & 4 \\
\hline Change in design and drawing & 4.80 & 3 & 3.89 & 13 & -10 & 100 \\
\hline Change in specifications or unclear specification & 4.40 & 7 & 3.78 & 17 & -10 & 100 \\
\hline Inaccurate quantity estimate or excess quantity during construction & 3.60 & 14 & 3.50 & 21 & -7 & 49 \\
\hline Cost underestimation & 3.60 & 15 & 3.89 & 11 & 4 & 16 \\
\hline The scope of work for the contractor is not well defined & 4.60 & 5 & 3.39 & 24 & -19 & 361 \\
\hline Kickbacks and fraudulent practices & 3.60 & 16 & 3.39 & 23 & -7 & 49 \\
\hline Delay of drawings and/or order requested by contractor & 3.80 & 11 & 3.89 & 10 & 1 & 1 \\
\hline Supplementary/additional agreement & 3.80 & 12 & 2.89 & 34 & -22 & 484 \\
\hline Delays in prompt decision making process & 4.20 & 7 & 3.83 & 16 & -9 & 81 \\
\hline Noncompliance of design with client's requirements & 3.80 & 13 & 3.72 & 18 & 5 & 25 \\
\hline Insufficient geotechnical investigation & 3.60 & 17 & 3.56 & 19 & -2 & 4 \\
\hline Differing site conditions & 4.60 & 6 & 3.94 & 8 & -2 & 4 \\
\hline Errors in setting out basing on incorrect written data supplied by the engineer & 3.20 & 20 & 3.50 & 22 & -2 & 4 \\
\hline Substitution of materials & 4.00 & 9 & 4.22 & 6 & 3 & 9 \\
\hline Difficulties in obtaining construction materials in the local market & 2.00 & 34 & 3.56 & 20 & 14 & 196 \\
\hline Unforeseen problems & 4.00 & 10 & 3.94 & 9 & 1 & 1 \\
\hline Conflict between contract documents & 3.00 & 24 & 3.11 & 28 & -4 & 16 \\
\hline Ambiguities or discrepancies of documents & 3.20 & 21 & 4.56 & 4 & 17 & 289 \\
\hline Addition or enhancement required by client or end users & 4.20 & 8 & 2.44 & 38 & -30 & 900 \\
\hline Lack of planning and coordination or less emphasis to planning & 3.00 & 25 & 3.32 & 25 & 0 & 0 \\
\hline Poor communication among contractor, consultant, and the client & 3.60 & 18 & 3.06 & 30 & -12 & 144 \\
\hline Cost associated with test of samples not provided in the contract & 4.80 & 4 & 2.89 & 33 & -29 & 841 \\
\hline Lack of end users involvement & 2.80 & 28 & 3.89 & 14 & 14 & 196 \\
\hline Increase in tax/change in Government fiscal/monetary policies & 2.00 & 35 & 3.94 & 7 & 28 & 784 \\
\hline Executive bureaucracy in the client's organization/staff & 2.80 & 29 & 2.78 & 35 & -6 & 36 \\
\hline Financial problems or funding problems & 2.00 & 36 & 3.00 & 31 & 5 & 25 \\
\hline Noncompliance of design with government regulations & 1.20 & 42 & 4.72 & 2 & 40 & 1600 \\
\hline $\begin{array}{l}\text { Failure to identify risks and institute necessary and timely remedy and control } \\
\text { program }\end{array}$ & 3.20 & 22 & 2.17 & 43 & -21 & 441 \\
\hline Poor procurement & 2.20 & 32 & 3.28 & 26 & 6 & 36 \\
\hline Inadequate project objectives & 2.00 & 37 & 3.89 & 12 & 25 & 625 \\
\hline Inappropriate/inexperience contractor & 2.00 & 38 & 2.94 & 32 & 6 & 36 \\
\hline Change of schedule & 3.00 & 26 & 2.56 & 19 & 7 & 49 \\
\hline $\begin{array}{l}\text { Failure on the part of the employer to give possession of the site to contractor } \\
\text { as agreed in the contract }\end{array}$ & 2.80 & 30 & 3.17 & 27 & 3 & 9 \\
\hline Obstinate nature of the owner & 2.20 & 33 & 3.83 & 14 & 19 & 361 \\
\hline Acceleration required by the client & 2.00 & 39 & 2.17 & 42 & 3 & 9 \\
\hline Safety considerations & 3.40 & 19 & 2.33 & 40 & -21 & 441 \\
\hline Indemnities that the employer has contractually undertaken to assume & 3.2 & 23 & 2.56 & 37 & -14 & 196 \\
\hline Contractors bankruptcy & 2.82 & 26 & 2.34 & 39 & -13 & 169 \\
\hline Political pressures at the time of construction & 1.8 & 41 & 3.11 & 29 & 12 & 144 \\
\hline Technology change & 2.80 & 31 & 2.11 & 44 & -13 & 169 \\
\hline Fossils or discovery of things of geological interest & 2.00 & 40 & 2.06 & 41 & -1 & 1 \\
\hline & & & & & $\sum d i^{2}$ & 9,014 \\
\hline
\end{tabular}

Note: (a) = MS consultant; (b) = consultant ranking; (c) = MS contractor; (d) = contractor ranking; (e) = difference in rank; $(\mathrm{f})=$ square of difference in rank 
Table 5 Summary of correlation tests client, consultant and contractor.

\begin{tabular}{lllll}
\hline Respondents & $I_{s}=1-\frac{6 \times\left(\sum d i^{2}\right)}{N \cdot\left(N^{2}-1\right)}$ & Perfect correlation & Significance & $\begin{array}{l}\text { Reject/accept null } \\
\text { hypothesis }\end{array}$ \\
\hline Client vs. contractor & 0.2168 & $-1.0 \leq I_{S} \leq 1.0$ & Significant & Reject \\
Contractor vs. consultant & 0.3648 & $-1.0 \leq I_{s} \leq 1.0$ & Significant & Reject \\
Client vs. consultant & 0.3038 & $-1.0 \leq I_{s} \leq 1.0$ & Significant & Reject \\
\hline
\end{tabular}

A summary of the result showing the correlation coefficient for all the three groups is shown in Table 5. relying on the significance of the perfect correlation of -1.0 for negative correlation and 1.0 for a perfect positive correlation, the three group cases are complying with the hypothesis that there is a significant agreement between the respondents, therefore rejecting the null hypothesis.

\subsection{Limitation of the Study}

Park and Papadopoulos [10] cite Olawale and Sun (2010) and Jha and Devaya (2008) who admit that although the causes of cost overrun in projects share common characteristics worldwide, they are also affected by country-specific conditions such as political, economic, legislative, social and cultural factors. The author hence has attempted to make Tanzania a case specific, though acknowledging the fact that the results have a wider application to similar economies. The author furthermore acknowledges the limited number of projects that could have influenced the results and also of the 44 factors of causes of cost overrun tested by the study may not be exhaustive as the respondents had to limit themselves to these when responding. The study, however, has underscored the importance of team thinking and a shared cognition as attributes that should not be taken for granted for team success.

\section{Conclusions}

In conclusion, the study has shown how clients, consultants and contractors prioritize causes of cost overrun in building projects and measured the statistical significance in the variance of ranking. The study has established the perceived five top factors attributing to cost overrun are mostly technical and originate from internal sources. This implicates high chances of successful mitigation.

Of the 44 causes of cost overrun affirmed by the respondents and use of Spearman's coefficient of correlation, the study has established existence of a strong correlation in ranking causes of cost over run amongst the actors, i.e., between client and contractor, between contractor and consultant; and between client and consultant. These imply key project actors agree on the causative factors of cost overrun in building construction projects. Such a perception is also a sound base for successful control of cost overrun as it is bound to instigate team effort [10]. The result of this study also conform to a survey of construction projects at Gaza Strip that established that there was agreement between contractors, consultants and clients regarding causes of delays and cost overruns [10].

The results are hence promising in which they have shown a pre-requisite attribute for effective team performance is in place; that there is a shared perspective on the prominent causes of building cost overruns hence it is expected that mitigation measures have a potential for successful implementation due to absence of a prioritization conflict. For a more proactive strategy, conceited efforts should be made by team players to create integral teams [3] and also enhance project team relations. The latter is crucial since empirical studies elsewhere [7] have established a positive association between project team relationships and project cost overrun.

\section{Acknowledgments}

The author acknowledges all respondents that had provided information during data collection. 


\section{References}

[1] Hung, W. 2013. "Team-Based Complex Problem Solving: A Collective Cognition Perspective." Educational Technology Research and Development 61 (3): 365-84.

[2] Chatterjee, S. 2016. "Enhancing Team Performance through Transactive Memory." Development and Learning in Organizations 30 (4): 13-6.

[3] Che Ibrahim, K. I., Costello, S. B., and Wilkinson, S. 2015. "Key Indicators Influencing the Management of Team Integration in Construction Projects." International Journal of Managing Projects in Business 8 (2): 300-23.

[4] Jetu, F. T., and Riedl, R. 2013. "Cultural Values Influencing Project Team Success: An Empirical Investigation in Ethiopia." International Journal of Managing Projects in Business 6 (3): 425-56.

[5] Coetzer, G. H., and Bushe, G. R. 2006. "Using Discrepancy Theory to Examine the Relationship Between Shared Cognition and Group Outcomes." Team Performance Management 12 (5/6): 155-61.

[6] Standifer, R. L., Raes, A. M. L., and Peus, C. 2015. "Time in Teams: Cognitions, Conflict and Team Satisfaction." Journal of Managerial Psychology 30 (6): 692-708.

[7] Dada, M. O. 2014. "The Influence of Project Team Relationships on Cost Growth." Journal of Financial Management of Property and Construction 19 (1): 76-94.

[8] Ahiaga-Dagbui, D. D., and Smith, S. D. 2014. "Rethinking Construction Cost Overruns: Cognition, Learning and Estimation." Journal of Financial Management of Property and Construction 19 (1): 38-54.

[9] Subramani, T., Sruthi, P. S., and Kavitha, M. 2014. "Causes of Cost Overrun in Construction." IOSR Journal of Engineering (IOSRJEN) 04 (06): 1-7.

[10] Park, Y., and Papadopoulou, T. C. 2012. "Causes of Cost Overruns in Transport Infrastructure Projects in Asia Their Significance and Relationship with Project Size." Built Environment Project and Asset Management 2 (2): 195-216.

[11] Ahsan, K. 2012. "Determinants of the Performance of Public Sector Development Projects." International Journal of Management 29 (1): 77-90.

[12] Love, P. E. D., Sing, C., Wang, X., and Yung, P. 2012. "Probability Distribution Fitting of Cost Overrun Profiles." Presented at RICS COBRA Conference, Las Vegas, NV, USA.

[13] Enhassi, A., Al-Najjar, J., and Kumaraswamy, M. 2009.
"Delays and Cost Overruns in Construction Projects in the Gaza Strip." Journal of Financial Management of Property and Construction 14 (2): 126-51.

[14] Avots, I. 1983. "Cost Relevance Analysis for Overrun Control." International Journal of Project Management 1: $142-8$.

[15] Amoa-Abban, K., and Allotey, S. 2014. "Cost Overruns in Building Construction Projects: A Case Study of a Government of Ghana Project in Accra." Developing Country Studies 4 (24): 54-64.

[16] Angelo, W. J., and Reina, P. 2002. "Cost-Relevance Analysis for Overrun Control." International Journal of Project Management 1 (3): 142-8.

[17] Morris, P. W. G., and Hough, G. H. 1991. The Anatomy of Major Projects. A Study of the Reality of Project Management. Chichester, UK: John Wiley and Sons.

[18] Arditi, D., Akan, G. T., and Gurdamar, S. 1985. "Reasons for Delays in Public Projects in Turkey." Construction Management and Economics 3: 171-81.

[19] Kaming, P. F., Olomolaiye, P. O., Holt, G. D., and Harris, F. C. 1997. "Factors Influencing Construction Time and Cost Overruns on High-Rise Projects in Indonesia." Management and Economics 15: 83-94.

[20] Mansfield, N. R., Ugwu, O. O., and Doran, T. 1994. "Causes of Delay and Cost Overruns in Nigeria Construction Projects." International Journal of Project Management 12 (4): 254-60.

[21] Elchaig, T., Boussabinaine, A., and Ballal, T. 2005. "Critical Determinants of Construction Tendering Costs: Quantity Surveyors' Standpoint." International Journal of Project Management 23 (7): 538-45.

[22] Peeters, W., and Madauss, B. 2008. "A Proposed Strategy against Cost Overruns in the Space Sector: The 5C Approach." Space Policy 24 (2): 80-9.

[23] Warsame, A. 2006. "Supplier Structure and Housing Construction Costs." Doctoral thesis, Division of Building and Real Estate Economics, Department of Real Estate and Construction Management, School of Architecture and Built Environment Royal Institute of Technology, Stockholm.

[24] Flyvbjerg, B. 2003. "Delusions of Success: Comment on Dan Lovallo and Daniel Kahneman." Harvard Business Review December: 121-2.

[25] Flyvbjerg, B., Holm, M. K. S., and Buhl, S. L. 2003. "How Common and How Large Are Cost Overrun in Transport Infrastructure Project." Transport Reviews 23 (1): 71-88. 